\title{
Plasma Levels of Atrial Natriuretic Peptide in Patients with Borderline and Essential Hypertension
}

\author{
Tetsuya Nakamura, Shuichi Ichikawa, Tetsuo \\ Sakamaki, Masao Fujie, Atsuko Yagi, Toshiaki \\ Kurashina and Kazuhiko Murata
}

The Second Department of Internal Medicine, Gunma

University School of Medicine, Maebashi 371

\begin{abstract}
Nakamura, T., Ichikawa, S., Sakamaki, T., Fujie, M., Yagi, A., Kurashina, T. and Murata, K. Plasma Levels of Atrial Natriuretic Peptide in Patients with Borderline and Essential Hypertension. Tohoku J. exp. Med., 1988, 154 (2), 205213 — Plasma levels of atrial natriuretic peptide (ANP) were measured in outpatients with borderline hypertension $(n=15)$ and essential hypertension $(n=$ $13)$ and in normotensive subject $(n=11)$. There were no significant differences among the three groups in age, serum protein, albumin, or electrolyte levels, plasma renin activity (PRA), or plasma concentrations of aldosterone and cortisol. The plasma ANP levels in the normotensive, borderline hypertensive, and essential hypertensive subjects were $36 \pm 6 \mathrm{pg} / \mathrm{ml}$ (mean \pm S.E.), $64 \pm 11 \mathrm{pg} / \mathrm{ml}$, and $82 \pm 14$ $\mathrm{pg} / \mathrm{ml}$, respectively. The levels in the essential hypertensive subjects were significantly $(p<0.05)$ higher than those in the normotensives. In both borderline and essential hypertensives $(n=28)$, the plasma ANP levels were significantly correlated positively with systolic blood pressure $(\mathrm{r}=+0.385, p<0.05)$, and negatively with PRA $(\mathrm{r}=-0.484, p<0.05)$ and serum total calcium $(\mathrm{r}=-0.516$, $p<0.01$ ). These results suggest that the elevation of circulating ANP in hypertensives is involved in the pathogenesis of hypertension. — atrial natriuretic peptide ; renin ; aldosterone ; essential hypertension ; calcium
\end{abstract}

Mammalian atria contain peptides with potent diuretic, natriuretic, and vasorelaxant actions. These substances, collectively termed atrial natriuretic peptides (ANP), have been purified, sequenced, and synthesized (Sagnella and MacGregor 1984). When injected into healthy volunteers, synthetic ANP induces natriuresis, diuresis and a decline in blood pressure (Richards et al. 1985). It has been demonstrated in humans that the level of circulating ANP rises in response to isotonic volume exapansion (Yamaji et al. 1985) or an increase in dietary sodium intake (Sagnella et al. 1987). Inhibitory effects of ANP on renin secretion (Villarreal et al. 1986) and aldosterone release from adrenal cells (Goodfriend et al. 1984) have also been reported.

In addition, it has been demonstrated (Richards et al. 1985; Weidmann et al.

Received November 9, 1987; revision accepted for publication January 28, 1988. 
1986) that urinary calcium output is increased by ANP infusion in normal volunteers. Several investigators (Kesteloot et al. 1983; Resnick et al. 1983 ; Kaplan and Meese 1986) have reported a close relationship between natriuresis and the level of circulating calcium. We reported previously (Nakamura et al. 1987) that urinary calcium excretion increased concurrently with a rise in plasma ANP levels, accompanied by natriuresis during mineralocorticoid escape phenomenon. We also observed a slight decrease in serum total calcium during hypercalciuria. These studies suggest that ANP plays an important role in the regulation of sodium, volume homeostasis and calcium, and may be involved in the pathogenesis of hypertension (Needleman and Greenwald 1986).

We measured plasma ANP levels in patients with borderline and essential hypertension and normotensive control subjects. Plasma renin activity (PRA), plasma aldosterone concentration, and serum calcium were also measured in an attempt to clarify the relationship between these variables and plasma ANP levels and to estimate a role of plasma ANP in the pathogenesis of hypertension.

\section{Subjects And Methods}

Before entering the study, 39 subjects were divided into 3 groups on the basis of repeated blood pressure measurements. One group comprised 10 males and five females with borderline hypertension. The second group included five males and eight females with essential hypertension. Eleven normotensive subjects (nine males and two females) served as a control group. Essential hypertensive subjects had a systolic blood pressure of 160 $\mathrm{mmHg}$ or above and/or a diastolic blood pressure of $95 \mathrm{mmHg}$ or above. Normotensive control subjects had a systolic blood pressure of $140 \mathrm{mmHg}$ or below and a diastolic blood pressure of $90 \mathrm{mmHg}$ or below. The remaining subjects were classified as borderline hypertensive subjects. None of the hypertensive subjects had a history of congestive heart failure, myocardial infarction, cerebrovascular accident, diabetes mellitus or renal disease. Secondary forms of hypertension were excluded according to the results of urinalysis and intravenous pyelography and measurements of serum creatinine, serum electrolytes, and urinary catecholamines. None of the hypertensive women was pregnant or taking contraceptives. Subjects with essential hypertension were either untreated or stopped taking antihypertensive medication more than 2 weeks before the study.

All subjects fasted for $12 \mathrm{hr}$ prior to the study. On the day of data collection, each subject remained in the recumbent position for at least $1 \mathrm{hr}$ and the mean of three separate sphygmomanometric measurements of supine blood pressure was recorded. A sample of venous blood was obtained for measurements of plasma ANP, PRA, and plasma concentrations of aldosterone and cortisol. Serum electrolytes, creatinine, albumin, and total protein were also measured. Sodium and potassium were measured by flame photometry and calcium by atomic absorption spectrophotometry. Serum concentrations of creatinine, albumin and total protein were determined by the autoanalyzer technique. PRA and plasma concentrations of aldosterone and cortisol were measured by radioimmunoassay, as reported previously (Ichikawa et al. 1984). For measurement of immunoreactive ANP, 1-ml plasma aliquots were extracted on Sep-PAK C18 cartridges (Waters Associates, Milford, MA, USA) (mean recovery, 81\%) before radioimmunoassay (sensitivity, $7 \mathrm{pg} / \mathrm{ml}$ ), as described previously (Nakamura et al. 1987). Synthetic $\alpha$-human atrial natriuretic peptide $(\alpha$-hANP) was purchased from Peninsula Laboratories (Belmont, CA, USA). ${ }^{125} \mathrm{I}-\alpha$-hANP and antibody against Atriopeptin I were kindly provided by Mitsubishi Yuka Laboratory of Medical Science. The intra- and interassay coefficients of variation were 7.0 
and $9.1 \%(n=10)$, respectively.

The data were analyzed statistically by Tukey's test for multiple comparisons preceded by one-way analysis of variance. Correlations between different variables were determined by linear regression analysis. Values are means \pm s.e. A $p$ value of less than $5 \%$ was considered significant.

\section{Results}

Table 1 lists the characteristics of the groups studied. There were no significant differences among the three groups in age, serum total protein, albumin, electrolytes, or creatinine. PRA and plasma concentrations of aldosterone and cortisol also did not differ significantly. Both systolic and diastolic blood pressures were significantly $(p<0.01)$ higher in the essential hypertensives than in the other two groups. Diastolic blood pressure was significantly $(p<0.05)$ higher in the borderline hypertensives than in the normotensives, but there was no significant difference in systolic blood pressure between these two groups.

The plasma levels of immunoreactive ANP in the normotensive, borderline hypertensive, and essential hypertensive subjects were $36 \pm 6 \mathrm{pg} / \mathrm{ml}, 64 \pm 11 \mathrm{pg} / \mathrm{ml}$ and $82 \pm 14 \mathrm{pg} / \mathrm{ml}$, respectively (Fig. 1). The value was significantly $(p<0.05)$ higher in the essential hypertensive than in the normotensive group. There were neither significant differences between the normotensive and the borderline

TABLE 1. Clinical and biochemical characteristics of subjects

\begin{tabular}{|c|c|c|c|}
\hline & $\begin{array}{l}\text { Normotensives } \\
\qquad(n=11)\end{array}$ & $\begin{array}{c}\text { Borderline } \\
\text { hypertensives } \\
(n=15)\end{array}$ & $\begin{array}{c}\text { Essential } \\
\text { hypertensives } \\
(n=13)\end{array}$ \\
\hline Age (years) & $34.7 \pm 3.6$ & $34.9 \pm 2.6$ & $42.8 \pm 2.3$ \\
\hline Systolic BP (mmHg) & $127 \pm 5$ & $140 \pm 2$ & $167 \pm 9^{* *} \dagger$ \\
\hline Diastolic BP (mmHg) & $73 \pm 3$ & $84 \pm 3^{*}$ & $105 \pm 2^{* *} \dagger$ \\
\hline \multicolumn{4}{|l|}{ Serum } \\
\hline Total protein $(\mathrm{g} / 100 \mathrm{ml})$ & $6.6 \pm 0.1$ & $6.8 \pm 0.1$ & $6.8 \pm 0.1$ \\
\hline Albumin (g/100 ml) & $4.3 \pm 0.1$ & $4.5 \pm 0.1$ & $4.3 \pm 0.1$ \\
\hline Sodium (mEq/liter) & $142 \pm 1$ & $141 \pm 1$ & $142 \pm 1$ \\
\hline Potassium (mEq/liter) & $4.1 \pm 0.1$ & $3.8 \pm 0.1$ & $3.7 \pm 0.2$ \\
\hline Calcium (mg/100 ml) & $9.23 \pm 0.11$ & $9.43 \pm 0.06$ & $9.31 \pm 0.08$ \\
\hline Creatinine $(\mathrm{mg} / 100 \mathrm{ml})$ & $1.0 \pm 0.1$ & $1.0 \pm 0.1$ & $1.1 \pm 0.1$ \\
\hline $\begin{array}{l}\text { Plasma renin activity } \\
(\mathrm{ng} / \mathrm{ml} / \mathrm{hr})\end{array}$ & $2.0 \pm 0.3$ & $2.8 \pm 0.6$ & $1.4 \pm 0.3$ \\
\hline \multicolumn{4}{|l|}{ Plasma } \\
\hline Aldosterone $(\mathrm{pg} / \mathrm{ml})$ & $109 \pm 13$ & $89 \pm 10$ & \pm 15 \\
\hline Cortisol $(\mu \mathrm{g} / 100 \mathrm{ml})$ & $11 \pm 2$ & $15 \pm 1$ & $14 \pm 2$ \\
\hline
\end{tabular}

Values are means \pm s.E.

${ }^{*} p<0.05,{ }^{* *} p<0.01$ compared with normotensive subjects.

$\dagger p<0.01$ compared with borderline hypertensive subjects. 


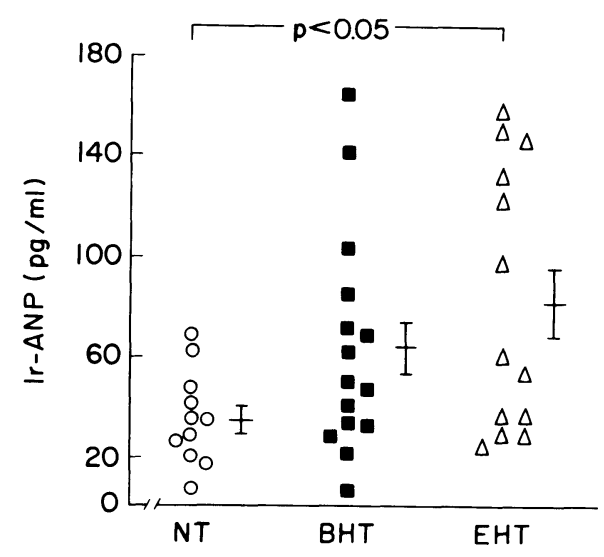

Fig. 1. Plasma levels of immunoreactive ANP (Ir-ANP) in normotensive (NT, $n=11$ ), borderline hypertensive (BHT, $n=15$ ), and essential hypertensive (EHT, $n=13$ ) subjects. Bars represent means \pm s.e.

hypertensive, nor between the borderline hypertensive and the essential hypertensive subjects. In both borderline and essential hypertensives, the plasma ANP level was positively and significantly correlated with systolic blood pressure $(n=$ $28, \mathrm{r}=+0.385, p<0.05)$, but not with diastolic blood pressure.

Fig. 2 shows the individual data of the plasma ANP levels and PRA for each group and a significant negative correlation are depicted between these two variables in all subjects. In both borderline and essential hypertensives, this correlation between plasma ANP and PRA was also significant $(n=28, \mathrm{r}=-0.484$,

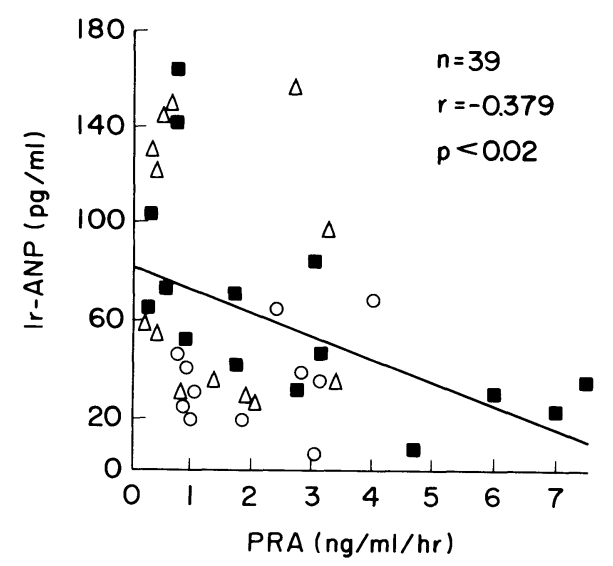

Fig. 2. Regression analysis of plasma renin activity (PRA) and plasma levels of immunoreactive ANP (Ir-ANP). Open circle, closed square and open triangle represent normotensive $(n=11)$, borderline hypertensive $(n=15)$ and essential hypertensive $(n=13)$ subjects, respectively. The line is a regression line $(\mathrm{y}=$ $81.6-9.21 x)$. 


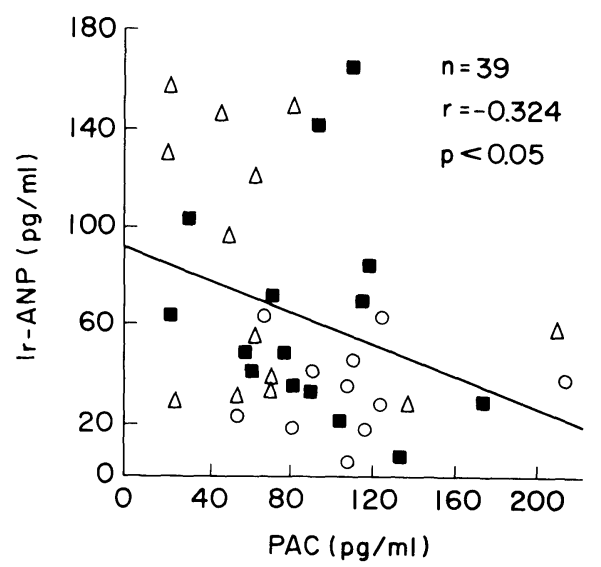

Fig. 3. Regression analysis of plasma aldosterone concentration (PAC) and plasma levels of immunoreactive ANP (Ir-ANP). Open circle, closed square and open triangle represent normotensive $(n=11)$, borderline hypertensive $(n=15)$ and essential hypertensive $(n=13)$ subjects, respectively. The line is a regression line $(y=89.8-0.31 x)$.

$p<0.05)$. As illustrated in Fig. 3 , the plasma ANP level was inversely and significantly correlated with the plasma aldosterone concentration in all subjects.

The serum calcium level did not differ significantly among the three groups (Table 1), and there was no significant correlation between plasma ANP and serum

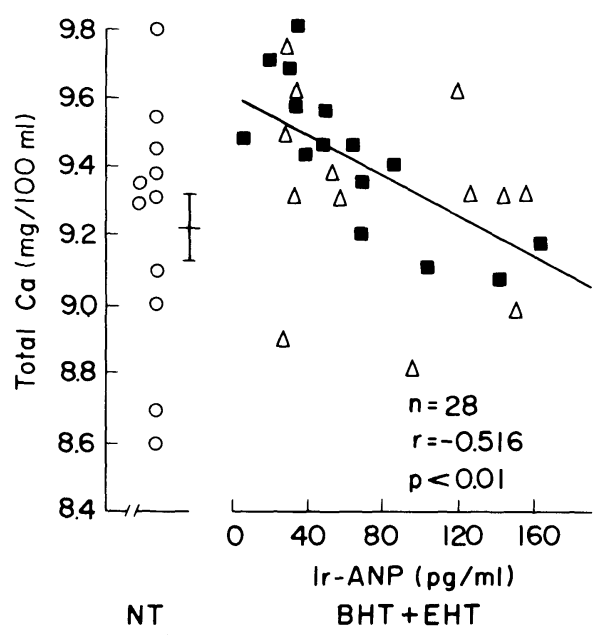

Fig. 4. Serum total calcium in normotensive subjects (NT) and regression analysis of plasma levels of immuncreactive ANP (Ir-ANP) and serum total calcium in borderline hypertensive (BHT) and essential hypertensive (EHT) subjects. Open circle, closed square and open triangle represent normotensive $(n=11)$, borderline hypertensive $(n=15)$ and essential hypertensive $(n=13)$ subjects, respectively. The bar in the normotensives is mean \pm s.e. The line in the hypertensives is a regression line $(y=9.57-0.0027 x)$. 
calcium in all subjects of the three groups together; however, as shown in Fig. 4, plasma ANP showed a significant inverse correlation with serum calcium in both hypertensive groups. There was a significant positive correlation between PRA and serum calcium in the hypertensive subjects $(n=28, \mathrm{r}=+0.359, p<0.05)$. Plasma ANP levels were unrelated to either serum total protein or serum albumin.

\section{Discussion}

The importance of the plasma ANP level in patients with essential hypertension is controversial. Sagnella et al. (1986) demonstrated that the level of circulating ANP is elevated in patients with essential hypertension, while Yamaji et al. (1986) found that the plasma ANP level in hypertensives did not differ significantly from that in normotensives. Our study have shown that the plasma ANP level is raised in a considerable proportion of outpatients with borderline and essential hypertension and that it is significantly correlated with systolic blood pressure. Naruse et al. (1986) also observed a significant positive relationship between the plasma ANP level and systolic blood pressure in patients with esential hypertension. The mechanisms of the increase in plasma ANP in hypertensive individuals remain to be elucidated. It may be a consequence of high dietary sodium intake, though urinary sodium excretion was not measured in the present study; in fact, ANP does rise in normotensive subjects who increase their dietary sodium (Sagnella et al. 1987). However, it has been described (Sagnella et al. 1986) that the elevation in plasma ANP in hypertensives is more likely a result of increased atrial secretion due to high atrial pressure, since a rise in atrial pressure in hypertensives has been reported (London et al. 1985).

Shenker et al. (1985) discovered a significant inverse correlation between the plasma ANP level and both PRA and plasma aldosterone concentrations in normal human subjects. ANP is reportedly a potent inhibitor of basal and angiotensin II-induced release of aldosterone from adrenal cells (Goodfriend et al. 1984). Moreover, infusion of the peptide suppresses plasma renin levels (Villarreal et al. 1986). Therefore, it has been suggested (Sagnella et al. 1987) that ANP influences sodium excretion through inhibition of the renin-angiotensinaldosterone system as well as through direct effects on renal function. In our investigation, the plasma ANP level in the hypertensive patients was significantly correlated with PRA. This implies that the increase in ANP in hypertensives may be involved, along with plasma renin, in sodium and volume homeostasis and thereby may participate in the maintenance of hypertension. It should be noted, as described by Sagnella et al. (1986), that the increase in ANP in essential hypertenion might be a compensatory mechanism to excrete the excess sodium retained by reduced sodium excretion, either as a results of an inherited renal abnormality or as a result of a decreased renal function by the high blood pressure.

It has been reported (Ladenson et al. 1978) that serum total calcium predict free calcium status better than calcium values corrected for protein, albumin and 
pH. Recently, Shibata et al. (1987) have reported a significant positive correlation between serum total calcium and blood ionized calcium in patients with essential hypertension. In the present study, the plasma ANP was inversely correlated with the serum calcium in the hypertensive subjects. Also, we observed that serum calcium was positively correlated with PRA. A close relationship between natriuresis and the level of circulating calcium has been reported. Resnick et al. (1983) observed that natriuresis induced by dietary salt loading was accompanied by hypercalciuria and a decline in the level of circulating calcium in hypertensive patients. Kesteloot et al. (1983) reported a negative and highly significant correlation between serum total calcium and 24-hr urinary sodium excretion in their epidemiological study. Moreover, Kaplan and Meese (1986) have suggested that the exaggerated natriuresis in hypertensives probably increases urinary calcium excretion and somewhat lowers the level of circulating calcium. Because it has been demonstrated (Richards et al. 1985 ; Weidmann et al. 1986) that urinary calcium output is increased by ANP infusion in normal volunteers, our finding of a significant inverse correlation between plasma ANP and serum calcium suggest that the increased ANP level in hypertensives may not only suppress PRA, but may also increase urinary calcium output and lower the serum level of calcium. Such a possible process in the regulation of calcium is in good accordance with some recently reported abnormalities of calcium metabolism in patients with essential hypertension, including increased urinary calcium excretion associated with compensatory parathyroid overactivity (McCarron et al. 1980 ; Stazzullo et al. 1983) and a significant positive correlation between the plasma level of ionized calcium and PRA (Resnick et al. 1986).

In conclusion, our results indicate that the plasma ANP level in hypertensive patients is increased relative to that in normotensives and is inversely correlated with PRA and serum calcium. Thus, the elevation in circulating ANP may be involved in the pathogenesis of hypertension.

\section{Acknowledgments}

We are very grateful to Miss Sayuri Iriya, Miss Akemi Yoguchi, and Mr. Yukihito Fukumura for their skillful technical assistance.

\section{References}

1) Goodfriend, T.L., Elliott, M.E. \& Atlas, S.A. (1984) Actions of synthetic atrial natriuretic factor on bovine adrenal glomerulosa. Life Sci., 35, 1675-1682.

2) Ichikawa, S., Tajima, Y., Sakamaki, T., Matsuo, H., Kogure, M., Hirano, Y., Yagi, S. \& Murata, K. (1984) Effect of spironolactone on fluid volumes and adrenal steroids in primary aldosteronism. Jap. Circulat. J., 48, 1184-1196.

3) Kaplan, N.M. \& Meese, R.B. (1986) The calcium deficiency hypothesis of hypertension: A critique. Ann. intern. Med., 105, 947-955.

4) Kesteloot, H., Geboers, J. \& Van Hoof, R. (1983) Epidemiological study of the relationship between calcium and blood pressure. Hypertension, 5, Suppl. 2, II 52-II 56 . 
5) Ladenson, J.H., Lewis, J.W. \& Boyd, J.C. (1978) Failure of total calcium corrected for protein, albumin, and $\mathrm{pH}$ to correctly assess free calcium status. J. clin. Endocr., 46, 986-993.

6) London, G.M., Safar, M.E., Safar, A.L. \& Simon, ACh. (1985) Blood pressure in the "low-pressure system" and cardiac performance in essential hypertension. J. Hypertension, 3, 337-342.

7) McCarron, D.A., Pingree, P.A., Rubin, R.J., Gaucher, S.M., Molitch, M. \& Krutzik, S. (1980) Enhanced parathyroid function in essential hypertension: A homeostatic response to a urinary calcium leak. Hypertension, 2, 162-168.

8) Nakamura, T., Ichikawa, S., Sakamaki, T., Sato, K., Kogure, M., Tajima, Y., Kato, T. \& Murata, K. (1987) Role of atrial natriuretic peptide in mineralocorticoid escape phenomenon in patients with primary aldosteronism. Proc. Soc. exp. Biol. Med., 185, $448-454$.

9) Naruse, M., Naruse, K., Obana, K., Kurimoto, F., Sakurai, H., Honda, T., Higashida, T., Demura, H., Inagami, T. \& Shizume, K. (1986) Immunoreactive $\alpha$-human atrial natriuretic polypeptide in human plasma. Peptides, 7, 141-145.

10) Needleman, P. \& Greenwald, J.E. (1986) Atriopeptin: A cardiac hormone intimately involved in fluid, electrolyte, and blood pressure homeostasis. New Engl. J. Med., 314, 828-834.

11) Resnick, L.M., Case, D.B., Pickering, T.G. \& Laragh, J.H. (1983) The effect of dietary sodium loading on divalent ions in hypertension. Kidney Int., 23, 109. (Abstract)

12) Resnick, L.M., Nicholson, J.P. \& Laragh, J.H. (1986) Calcium metabolism in essential hypertension: Relationship to altered renin system activity. Fed. Proc., 45, 2734-2738.

13) Richards, A.M., Nicholls, M.G., Ikram, H., Webster, M.W., Yandle, T.G. \& Espiner, E.A. (1985) Renal, haemodynamic, and hormonal effects of human alpha atrial natriuretic peptides in healthy volunteers. Lancet, 1, 545-548.

14) Sagnella, G.A. \& MacGregor, G.A. (1984) Cardiac peptides and the control of sodium excretion. Nature (Lond.), 309, 666-667.

15) Sagnella, G.A., Markandu, N.D., Shore, A.C. \& MacGregor, G.A. (1986) Raised circulating levels of atrial natriuretic peptides in essential hypertension. Lancet, $\mathbf{1}$, 179-181.

16) Sagnella, G.A., Markandu, N.D., Shore, A.C., Forsling, M.L. \& MacGregor, G.A. (1987) Plasma atrial natriuretic peptide: Its relationship to changes in sodium intake, plasma renin activity and aldosterone in man. Clin. Sci., 72, 25-30.

17) Shenker, Y., Sider, R.S., Ostafin, E.A. \& Grekin, R.J. (1985) Plasma levels of immunoreactive atrial natriuretic factor in healthy subjects and in patients with edema. J. clin. Invest., 76, 1684-1687.

18) Shibata, S., Kikuchi, K., Yamaji, I., Nozawa, A., Nishimura, M., Aoki, K., Hasegawa, T., Komura, H., Suzuki, S., Yamamoto, M. \& Iimura, O. (1987) The pathophysiological role of blood ionized calcium in essential hypertension. Jap. Circulat. $J ., 51,1223-1225$.

19) Strazzullo, P., Nunziata, V., Cirillo, M., Giannattasio, R., Ferrara, L.A., Mattioli, P.L. \& Mancini, M. (1983) Abnormalities of calcium metabolism in essential hypertension. Clin. Sci., 65, 137-141.

20) Villarreal, D., Freeman, R.H., Davis, J.O., Verburg, K.M. \& Vari, R.C. (1986) Renal mechanisms for suppression of renin secretion by atrial natriuretic factor. Hypertension, 8, Suppl. 2, II 28-II 35.

21) Weidmann, P., Hasler, L., Gnädinger, M.P., Lang, R.E., Uehlinger, D.E., Shaw, S., Rascher, W. \& Reubi, F.C. (1986) Blood levels and renal effects of atrial natriuretic peptide in normal man. $J$. clin. Invest., 77, 734-742.

22) Yamaji, T., Ishibashi, M. \& Takaku, F. (1985) Atrial natriuretic factor in human 
blood. J. clin. Invest., 76, 1705-1709.

23) Yamaji, T., Ishibashi, M., Sekihara, H., Takaku, F., Nakaoka, H. \& Fujii, J. (1986) Plasma levels of atrial natriuretic peptide in primary aldosteronism and essential hypertension. J. clin. Endocr., 63, 815-818. 